\title{
Democracy a mixed blessing
}

\section{Gdansk \& Krakow}

DEMOCRACY has run riot in Poland's universities. Under a law passed last year, the rectors who head Poland's top institutions of higher education must be elected by university staff and students, and will be called to account in repeat ballots every three years. Although faculty members did have some influence in the appointment of rectors previously, the final choice lay with the government. Not surprisingly, the first free elections in 1990 brought a host of new faces to the pinnacle of Polish academic life.

At the University of Gdansk, Zbigniew Grzonka confesses that he was initially a reluctant occupant of the rector's office - before being chosen by his colleagues to run the university, Grzonka was planning to travel abroad to continue his research in chemistry. Grzonka is now working energetically to purge the university of the legacy of Communism. But ironically, last year's legislative reforms, which guaranteed university autonomy, are proving to be an obstacle, as well as an opportunity.

Grzonka is trying to coax those departments where teaching and research was stongly influenced by the Communist ideology - such as the economics faculty - back towards the academic mainstream. But the reforms of 1990 have given a large degree of autonomy to faculty deans, who are also elected. Not surprisingly, in departments dominated by ex-Communists, Grzonka's calls for reform are going largely unheeded. "Now the freedoms are working against us," says Maciej Zylicz, prorector for scientific affairs. Coming from a Solidarity strike organizer whose own fight for freedom brought exile from Poland for two years in the early 1980s, Zylicz's sense of frustration is felt deeply.

Despite the problems, Grzonka and Zylicz are making progress. Grzonka controls the university's budget, so can reduce funding to departments that fail to reform their teaching. And he has also succeeded in setting up an independent western-style business school, where graduates will receive degrees from the University of Strathclyde, in Scotland. When Grzonka can be sure that the school will not come under the influence of the Communist old guard, he hopes to integrate it into the university.

Andrzej Pelczar, rector of the Jagiellonian University in Krakow, finds himself in a more fortunate position. Unlike the University of Gdansk, which was established by Poland's Communist government in 1970 , the Jagiellonian has a strong tradition of independence which helped the university to continue to manage its internal affairs free from excessive political interference through most of the post-war period. (Founded in 1364 , the Jagiellonian is one of Europe's oldest universities.) "Our university was not broken at all. We saved our identity," says Pelczar.

Pelczar stresses that the democratization of Poland has not brought about revolutionary changes at the Jagiellonian - they simply were not needed. But the new political climate will allow Pelczar to tackle some undesirable hangovers from the Communist era. In the 1950s, Poland's universities were shorn of their medical schools, which were reconstituted as separate medical academies, linked to the health ministry. The Jagiellonian is expected to be the first Polish university to welcome its medical school back into the fold, perhaps within the next eighteen months. Both institutions should gain from the move. Medical graduates will benefit by receiving degrees from an internationally known university, rather than a relatively obscure academy. And the return of medicine to the Jagiellonian will bring it in line with top flight universities abroad. At present, Pelczar finds it difficult to explain to his counterparts abroad how a leading university does not have a medical school.

As the depressed state of the Polish economy brings financial hardship to the universities, the Jagiellonian may be better placed than most. Pelczar hopes that his university's international reputation will attract funds from abroad already the Mellon Foundation, a US charity, has paid for computerization of the university library. But the Jagiellonian also has some earning potential, in the form of a new conference centre, complete with a 160-bed hotel. Although the centre has taken 20 years to build, during which time other development plans were severely restricted, it is now fully booked for the year ahead, and will be a important source of funds.

\section{Entrepreneurs look for customers}

\section{Gdansk}

"I'm not the type of person who can wait for money to drop from the sky," says Anna Podhajska, of the University of Gdansk's department of microbiology, explaining her efforts to commercialize the work of her research group. In Califormia, it may be common for university molecular biologists to double as biotechnology entrepreneurs, but in Poland, Podhajska is one of a rare breed.

Even before the Communist government's demise, Podhajska was beginning to interest western biotechnology companies in the restriction enzymes, plasmid DNA and other products produced by her group. Until now, her earnings have had to be in the form of reagents and other payments 'in kind', because the university could not accept cash payments on behalf of its employees. But all that is set to change: the university has set up a private foundation, numbering President Lech Walesa among its founders, which will for the first time allow Podhajska to earncash. The French company Appligene, and Life Technologies of Maryland, are poised to become her first customers.

Podhajska's enthusiasm is infectious. Visitors to her university office are swiftly whisked out of the department, and into a neighbouring building housing her pride and joy: the new biotechnology laboratory that is the centre of her commercial operation. Finding space for Podhajska's new venture was difficult, but in 1989 , university administrators agreed that she could convert an old kitchen, which for- merly served an austere adjoining student residential block (dubbed 'the Hilton' by its inmates). Luckily for Podhajska, her requests for money to buy equipment coincided with a temporary period of relative plenty for Polish scientists, under the initial Solidarity government of Tadeusz Mazowiecki, and the laboratory was completed in late 1990.

After returning some of her earnings to the university (part of the deal that won her the laboratory space was that a proportion of any profits would help with the Hilton's upkeep), Podhajska's priority is to reward her young research assistants, supplementing the $\$ 100$ a month they get from the university. "I'm here to make their lives decent," she says.

With the deep recession in the Polish economy squeezing spending on science, Podhajska's example may be a useful one for others to follow - and loans from the new Foundation for Polish Science (see page 385 ) may help other academics with commercial ambitions. But after over 40 years of Communist rule, few researchers share Podhajska's entrepreneurial spirit. And even for Podhajska, a commercial strategy is not without its costs. Until 1990, she kept her own laboratory bench space in Gdansk. But with an increasing amount of her time spent on administration, and in courting western biotechnology companies, Podhajska finds she has time to work on her own basic research only during her regular visits to the United States. 